\title{
Doing Justice Intelligently in Civil Society
}

\author{
John Braithwaite* \\ Regulatory Institutions Network, Research School of Social Sciences, \\ Australian National University
}

Empirically, justice might be immanently holistic—with procedural, distributive, restorative, and social justice positively correlated. Restorative justice may be about creating spaces where the various imperfectly correlated facets of holistic justice might cohere. State institutions of justice (such as criminal courts) with deeply embedded traditions of narrowing the meaning of justice (to proportional punishment, for example) are less fertile soil for holistic justice than civil society. Beyond a move to holism and to civil society, the contributions to this special issue imply a move to what Sherman calls "emotionally intelligent justice." This means nurturing the expression of vulnerable emotions and trying to avert the provocation of aggressive or stigmatizing emotions.

\section{Restorative Justice and Criminal Justice}

An impressive feature of this special issue is the way it draws upon data from societies as diverse as the United States, Australia, New Zealand, South Africa, and Bangladesh. This reflects the fact that restorative justice is now a global social movement for the transformation of legal justice. Its heartland is criminal law where 2000 saw all nations at the UN Congress on the Prevention of Crime and Treatment of Offenders vote to encourage the development of restorative justice programs. But restorative justice is proving an increasingly influential idea in programs for the care and protection of abused or neglected children, school bullying, business regulation, and international peacekeeping and peacemaking, among other domains (Roche, this issue). As Maxwell and Morris (this issue) explain, New Zealand research and development on the idea of family group conferences to respond to youth offenders was particularly important in the history

\footnotetext{
* Correspondence concerning this article should be addressed to John Braithwaite, Regulatory Institutions Network, Research School of Social Sciences, Australian National University, ACT-0200, Australia [e-mail: John.Braithwaite@anu.edu.au].
} 
of restorative justice. Yet perhaps even more influential, in terms of how widely it has been copied in the northern hemisphere, has been New Zealand's development of the conferencing idea for application to care and protection conferences with the families of abused or neglected children. In academic writing and social movement politics, as in the mass media, criminal justice always grabs more headlines than other forms of social regulation.

A more principled reason, however, for the prominence given to criminal justice in this special issue is that it is the criminal side of restorative justice innovation that has also attracted most research efforts, including some randomized controlled trials that have found substantial effects of restorative justice in reducing subsequent reoffending, though only for some kinds of offenders (Sherman, 2003), and in reducing the suffering of victims of crime (Strang et al., this issue). In 2001, the Canadian Department of Justice was able to conduct a meta-analysis of no fewer than 32 evaluations of restorative justice with credible controls (Latimer, Dowden, $\&$ Muise, 2001). It found a modest though significant association of restorative justice with lower reoffending, higher perceptions of fairness by victims and offenders, and superior implementation of agreements/orders in restorative justice compared to control cases. A recent updated and refined Canadian government meta-analysis by Bonta, Jesseman, Rugge, and Cormier (2006) replicated this result on reoffending, while reporting that the effect size was significantly greater for studies published from 1996.

While almost all developed nations and many developing ones have restorative justice programs for youth offending today, they mostly remain marginal programs, very much in the shadow of the punitive paradigm that continues to dominate youth justice. This is a second reason why New Zealand has special significance. It is the only nation where restorative justice is the mainstream, presumptive path for youth offending. As the Maxwell and Morris article shows, unless the offence is murder or manslaughter, youth offences always go either to a restorative police caution, a restorative diversion, a family group conference, or to court followed by a conference. They simply never go the court-punishment route bypassing any restorative process. While many other countries, such as Austria and Norway, have massive restorative justice programs, New Zealand remains distinctive because restorative justice consistently trumps punitive courtroom justice as the presumptive path for youth.

The impact has been substantial, cutting youth custodial sentences to around a third of what they had been prior to the restorative justice reform. As Maxwell and Morris point out, New Zealand is also interesting for the bicultural way its restorative justice programs have developed-influenced by Maori custom and law, eschewing other parts of that tradition, and incorporating notions such as victim rights from Western legal traditions. Restorative justice is not a nostalgic longing for a lost past, but practical experimentation into the future with learnings from both the past and the present. 
The New Zealand innovation of moving beyond one-on-one victim-offender mediation to a conference where family members and other supporters of both the offender and of the victim attend, as well as representatives of the state and/or the community, was a step with many implications. It makes the imbalance of power dynamics quite different, more muddied. Instead of a mediation between say a domineering male adult and a dominated female child, we have a conference for the same incident in which there may be adults and children, men and women, more and less domineering and articulate people on both sides. The Maxwell and Morris (1993) program of empirical research has been among the most important contributions on this question, showing that adult womens' voices, particularly mothers' voices, are greatly empowered by the conference process, though children's voices are still rather more muted than advocates would like to see. Aral, Burris, and Shearing (2002) found in their analysis of 942 South African peacemaking gatherings on the Zwelethemba model that is discussed by Roche (this issue) that $60 \%$ of the participants and $65 \%$ of the facilitators were women.

The shame dynamics discussed in the latter part of this special issue are different in a conference than in a dyadic mediation. Criminal offenders are often criminal offenders because they are good at shielding themselves from the consequences of the harm they have inflicted on others. Meeting the victim can make this harder. But still the shield that protects them from confronting the consequences of what they have done can continue to work as they sullenly stare at the ground while the victim recounts her suffering. We sometimes observe, however, that if an offender's mother begins to sob as she listens to the suffering of the victim, the offender will be more vulnerable to his mother's pain and to her compassion and humanity. So the New Zealand innovation of the conference in my view brought more complex emotional dynamics that were more productive in engendering empathy. This connected to Maori ways of thinking about justice, which saw it as barbaric to allow an offender to stand alone accused of a crime. The offender should be surrounded by the support of his loved ones in the face of terrible allegations against him and they should stand ready to share the burden of the responsibility that falls to him. From the shame management perspective that we see in the articles by Harris, Ahmed/Braithwaite, and Morrison (this issue), the shame of letting one's family down is easier to transcend. We can put it behind us in a ritual that emphatically demonstrates the forgiveness and support of our family.

A conference places less of a burden on the facilitator than a dyadic mediation places on the mediator. When dominating or abusive speech breaks out in a conference, hopefully there will be someone else in the circle who will speak to curb the dominating speech. If the offender says something to a victim that leaves him bereft of hope, there will mostly be someone else in the circle who will offer the victim comfort and support. When in a dyadic mediation only the mediator is available to comfort the cruelly treated or to put down dominating speech, 
the mediator risks being seen as on the side of the party on whose behalf she must intervene. More importantly, when the mediator is forced to intervene in this way, the empowerment philosophy of restorative justice-that power rests with the stakeholders rather than the professional—is put at risk. Dyadic mediations are therefore also more vulnerable to the incompetent mediator. In contrast, empowered conference participants often speak up to compensate for the incompetence of the worst facilitators. The conference ideology is to empower citizens as opposed to professionals. Neither incompetent citizens nor an incompetent facilitator need be fatal. So we do see, in our observational research, conferences that are conducted with massive incompetence on the part of the facilitator, combined with some equally clumsy interventions by some stakeholders, but conferences that are nevertheless successful because of competent interventions by other empowered citizen stakeholders.

Finally, the existence of a wider plurality of voices in the conference circle than in a dyadic mediation means that there are better prospects for creative problemsolving ideas to emerge. There are also more people who can offer ideas and practical help for plural forms of support to ensure that agreements are honored. So if it is decided that an anger management program would be a good idea, but then someone points out that a court once before ordered anger management and the offender rarely turned up, a relative might offer to pick her up every Tuesday evening to take responsibility for ensuring that this time she attends regularly. Plurality of perspectives enriches the problem-solving part of the conference. This is not to say that there might not be certain ideas that could only be broached by an adjournment in which the two principal players in the idea talk about it one-onone. Backstage, during coffee breaks, "private family time," farewells in the car park after the conference, we observe all manner of dyadic and triadic healing to be given space to occur. A research agenda for the future of restorative justice is about how to enable moving back and forth between wider and narrower groups of stakeholders to maximize restoration of victims, offenders, and communities of relationships.

An irony in the aftermath of the mainstreamed paradigm change of New Zealand conferencing is that today we probably see more innovation with radically new modalities of restorative circles in North America, especially Canada, than in the Antipodes. In the United States where restorative justice is utterly at the margins of an overwhelmingly punitive system, there is no mainstream orthodoxy of restorative justice. Consequently, in the many hundreds (Bazemore \& Schiff, 2005) of little community programs that are eked out of the punitive mainstream, creativity reigns. An example is the North Minneapolis African American Circles. Here a series of circles are held for each offender. The first is an interview circle where the program is described in detail so the young offender can make a decision on whether to participate in the program. The crime itself is not discussed in this circle. In one of them observed by Declan Roche, it was discovered 
that the young person was interested in basketball, so some men in the circle went to watch him play during the next week. The second circle discusses the harm caused by the crime and what might need to be done to put things right. Meanwhile a separate circle is being held to support the victim. The two circles can then decide to come together for a more conventional healing circle in which victims, offenders, and their supporters meet. After a plan of action is agreed in that circle, a follow-up circle is scheduled for some months into the future to monitor implementation. Finally, a celebration circle is held when the agreement is completed. This elaborate set of circles is of course very time consuming and is only affordable because almost all the work is put in by community volunteers. My point is that it is innovative, indeed pathbreaking, but that the innovation is incubated on the fringe of a U.S. justice system that leaves citizens in high crime communities such as North Minneapolis so dissatisfied with the way the system grinds down both offenders and victims that they become grass-roots justice innovators.

\section{Justice That Is Restorative}

A number of the contributions to this issue-in particular those of Roche, Pennell, Ahmed/Braithwaite, and Morrison-are about restorative justice for mostly non-criminal matters. Yet restorative justice has a core focus that is more specific than problem solving or conflict resolution of any kind. Its ultimate concern is some kind of injustice that must be dealt with. It might be confronted by conflict resolution, but equally by conflict prevention or problem solving, so long as what is at issue is injustice prevention or resolution of injustice. An injustice does not need to be a criminal harm, it can be a tort or some other kind of civil wrong, it can be the injustice of a school bully who teases other children (Ahmed/Braithwaite, Morrison, this issue), of families who neglect their children (Pennell, this issue), of corporations who treat their workers unfairly, armies fighting a war, or local communities that fail to provide basic security for citizens (Roche, this issue).

The justice idea has also become theoretically central for restorativists. This is why Tom Tyler's (1990) work is so pivotal. Because restorativists talk justice, they should walk the talk-be just in the way they transact restorative justice. The implication of Tyler's (this issue) work is that we are not likely to restore if we are not procedurally fair in the process of restoration. Barnes (1999) and Strang's (2002) work based on random assignment of criminal cases (to court versus restorative justice conferences) suggests that restorative processes mostly are perceived by offenders and victims as more procedurally fair than courtroom justice. It may be that restorative justice is perceived as more procedurally fair because stakeholders are given a direct voice rather than having to channel their communication through the mouthpiece of a lawyer. Yet there seems more to it 
than that. The Sherman et al. (1998), Barnes (1999), and Strang (2002) randomized control trial data also suggest that victims and offenders are more likely to perceive their rights as respected, that they are not discriminated against on the basis of the race, sex, age, etc., and various other facets of procedural justice beyond voice, when justice is transacted restoratively.

It may be that justice is immanently holistic. This idea comes through in Bishop Tutu's interpretation of the meaning of the Xhosa concept of ubuntu (see Roche, this issue). Ubuntu seems to incorporate not only restorative and procedural justice, but distributive justice (people with ubuntu "share what they have") and relational justice ("We belong in a bundle of life"). I want to read Tutu (1999) as reading ubuntu as holistic justice. Rather than regarding legal justice and social justice as quite separate things with separate institutions being best equipped to deliver them (say the criminal justice system for legal justice, the welfare system for social justice) we regard legal and social justice as facets of justice conceived more holistically. It follows that we might want to craft institutions that promote holistic justice making, as opposed to specializing in one kind of justice or another.

While justice may be to some extent immanently holistic, it cannot be totally holistic; otherwise there would be no point in distinguishing procedural justice from the justice of outcomes. Procedural justice has been conceived in the literature as having a number of facets-including consistency, correctability, decision accuracy, impartiality, ethicality, and process control (Lind \& Tyler, 1988; Leventhal, 1980) — but these facets tend to be moderately highly intercorrelated. Second, we find that procedural and distributive justice tend to be positively correlated (Wenzel (2000, 2002) reporting correlations of 0.2-0.4). Hence, one of the arguments of restorative justice theorists has been that restorative justice, compared to existing justice practices, contributes to procedural justice, perceived fairness of outcomes (distributive justice) and indeed social justice (Braithwaite, 2002: pp. 54-130). Zehr (1995) argues that this holism in the conception of justice is to be found in the biblical notion of justice as shalom. The intuition about the immanent holism of the shalom way of thinking about justice is that a restorative justice process that seeks to empower stakeholders to repair the harm of an injustice will produce outcomes that are more distributively satisfying to stakeholders than a process that seeks to deliver equal punishments to equal wrongs. If we put the problem in the center of the circle, as opposed to putting the person in the center, we are more likely to come up with a solution to the problem that is perceived by the participants to deliver just distributive benefits. In contrast, if we put the person in the center of the circle and ask what is the right punishment according to some narrowly punitive theory of justice, it will turn out that the right punishment according to this theory will almost always be the wrong solution to the problem. Punitive justice can be integrated into holistic justice. Sometimes it is vital to protect community safety and to deliver distributive benefits to potential victims of injustice through 
deterrence. But punitive justice is not the main game of holistic justice. When lawyers make it the main game by insisting on consistent application of the principle of equal punishment for equal wrongs, holistic justice is placed beyond our reach.

Heather Strang's (2002) writing suggests that a narrower just deserts objective allows less leeway for a wider contract zone in which a win-win outcome can be crafted where both victims and offenders can be better off than they would have been without the encounter with the justice system. Strang's (2002) evidence that win-win outcomes are more likely in restorative justice conferences, while winlose and lose-lose victim-offender outcomes are more likely in courtroom justice, means restorative justice produces outcomes that are more generally conceived as distributively fair.

Strang et al. (this issue) show that the way victims can improve their circumstances through restorative justice are various. In their randomized controlled trials, victims in restorative justice processes are more than twice as likely to be afraid, to be angry, and less than half as likely to be sympathetic to offenders before compared to after restorative justice conferences. Referring also to Angel's (2005) results on the impact of restorative justice in reducing post-traumatic stress, Strang et al. come up with the innovative theoretical interpretation that when restorative justice is a successful interaction ritual (Collins, 2004), it may give victims the emotional energy to gain cognitive mastery of their emotions, supplanting conditioned fear with empathy for an offender in dire life circumstances. Hence, another dimension of the potential holism of restorative justice is that the justice it theorizes in the Strang et al. contribution, is not simply justice for offenders, but for all stakeholders affected by the injustice, including its direct victims.

Law that is seen as legitimate, and therefore as enabling self-regulation, also underwrites a more holistic justice than law that is seen as illegitimate and that must be externally coerced (Tyler, this issue). Such coerced, illegitimate law is a law of the authorities, rather than the law of a whole people, a living law of a civil society.

We have seen that greater control of process in the hands of stakeholders, as opposed to justice professionals, might also explain why restorative justice is perceived as more procedurally fair. We can also intuit why justice may be immanently holistic by going in the opposite direction in ways suggested by the writings of Rawls (1971) and indeed most other writers on justice. An unjust procedure will be more open to domination by the person with the most power rather than the person with the best case and so will lead both to less fair outcomes and to social injustice by virtue of domination by the powerful. Relevant to this prospect of holistic justice through restorative institutions is the earlier claim about how restorative justice creates more cross-cutting and counterbalanced power imbalances than an encounter between a domineering male and a dominated woman, an adult and a child, a school bully and a nerd, a sophisticated corporate criminal and 
an unsophisticated consumer, a fast-talking lawyer, and a slow-talking mentally disabled victim of crime.

The fact that justice is not fully holistic - that procedural and distributive justice often conflict, for example-means that there is value and great intellectual interest in studying the tensions between different versions of justice. Tom Tyler's (Tyler, 1990; Tyler \& Blader, 2000; Tyler \& Dawes, 1993; Tyler \& Huo, 2001) work on why the justice of procedures matters more than the distributive justice of outcomes is a pre-eminent example. Restorative justice innovation takes a different tack, however. It says that because there appears to be an immanent holism of justice as ubuntu or shalom, why not search for institutional ideas that maximize the synergy of holistic justice? Then it theorizes restorative justice as that institutional idea. For example, there is the theory of the structure of a restorative justice conference in comparison to that of a court case. We invite to a court case those who can, through their testimony, inflict maximum damage to the other side. We invite to the conference those who can offer maximum support to their own side, be it the victim or the offender side. Such plurality forces us to see civil society rather than the state as the most important sites where justice making is done. This is one interpretation of why Declan Roche (2003, see also Roche, this issue) was able to demonstrate superior capabilities for some forms of restorative justice to hold police accountable to citizens affected by excessive use of force and unfair victimization, compared to courtrooms.

Braithwaite (2002: pp. 17-24) has shown how Australian corporate crime enforcement that is restorative and responsive can foster a public discussion that transforms the regulation of an industry or create a tax system that is more structurally just in the burdens it imposes on super-rich individuals and corporations, in comparison to the poor (Braithwaite, 2005). Whether we are dealing with tax compliance, nursing home regulation, fraud by major insurance companies, or police threats to the security of a poor community, structural change that conduces to social justice is an emergent possibility from restorative justice innovation. In routine practice, however, structural transformation is rarely a feature of restorative justice (Braithwaite, 2001; White, 2003).

According to restorative justice theory, stigmatization of the person as a bad person causes defiance (Ahmed, 2001; Sherman, 1993), perceptions of procedural injustice, refusal to engage with reparative justice, and an increase in reoffending (that increases the amount of injustice in the world).

\section{Restorative Justice or Restorative Practices in Civil Society?}

Wachtel and McCold (2001) conceptualize a continuum of restorative practices. Their most limited restorative intervention is an "affective statement": "Mary, you sort of hurt my feelings when you did that." Longer interventions are triggered by "affective questions": "How do you think Jim felt when you did that?" These 
interventions can be transacted in workplaces, schools, and families on the run, when we encounter people in the corridor. As "affective statements," they pick up Scheff's (1994) idea of seeking to expose vulnerable emotions rather than aggressive emotions. The next level along Wachtel and McCold's (2001) restorative practices continuum is a "small impromptu conference." Informal police cautions can be adapted to this form; the police officer immediately takes a young offender detected of shoplifting home to her parents and all members of the family who are home sit down on the spot to discuss with the police officer what can be done to prevent this from happening again. Finally, the restorative practices continuum can be escalated to circles or conferences of varying composition, degrees of formality, and degrees of ritual significance. And as discussed earlier, larger circles might be broken out into one-on-one mediations in adjournments at various stages of more encompassing community gatherings. Obviously in social life we never have the time or resources for fully fledged restorative processes day by day. Nevertheless, we can learn why an affective question like "How do you think Jim felt when you did that?" is more restorative than yelling at or lecturing a child with: "You're a naughty boy for doing that to Jim."

Wachtel and McCold favor restorative practices as a more general conceptualization of what they study and practice than restorative justice. For them restorative practices are about restoring relationships or social capital, where social capital is conceived as connections among people, trust, and mutual understanding that makes cooperative problem solving possible (Putnam, 2000). Because restoring connectedness is a step toward restoring justice in restorative justice theories, restorative practices should also be directly useful for building social capital in civil society. The disparate range of restorative practices to which Roche (this issue) refers-from Hawkins' (2002) discussion of negotiated corporate regulation to Alternative Dispute Resolution—might be conceived as not fundamentally about justice much of the time. For example, the South African Truth and Reconciliation philosophy of ubuntu is described by Roche through the words of Desmond Tutu as "the restoration of broken relationships." As Roche also points out, it is important to be culturally plural about how we think about the substance of what is being called restorative justice in this issue. Hence, if in a particular cultural context there is more resonance, identity affirmation, and pragmatic problem solving in conceiving of family group decision making as about relationships rather than justice, why not do so?

This leads us in the next section to consider in more detail family group decision making in Pennell's (this issue) work, which might equally be conceived as about promoting justice or as about strengthening relationships in civil society (just as Morrison's (this issue) work might be as well conceived in a frame of promoting connectedness as promoting justice). For the social scientist, there can be empirical resolution of these conceptual dilemmas. There is a well-developed literature on how to measure social capital arising from the work of Putnam (2000) 
and others, just as there is a sophisticated literature on perceptual measures of justice from the scholarship of Tyler (this issue) and others. Models can be built where the size of social capital effects and justice effects are put in contest in explaining phenomena like the recovery of victims from trauma and the desistance of perpetrators. But it might be that the big story here is also more holistic. There can be no justice in a world without connectedness and empathy; at the same time, social capital cannot flourish in a world without an infrastructure of security around human relationships that can only be guaranteed by institutions of justice.

This relational way of thinking about holistic justice (Burnside \& Baker, 1994) is not new. As Strang et al. (this issue) point out, it was a major theme in the Scottish enlightenment, from David Hume's writings about justice, which give prominence to empathy, to Adam Smith (1790) in his writing on sympathy. Recent neuroscience suggests that the Scottish Enlightenment thinkers may have been right in seeing empathy as inherent to being human, and as a guarantee of the justice that allows us to survive without killing one another. Singer et al. (2004) report that the ability to appreciate the agony of others lights up the same parts of the brain that we use to feel pain ourselves. Feeling our own pain and feeling the pain of others may be embedded in the same elements of a biology that makes humans fit for survival. In contexts of obligation, we have learnt to conceptualize feeling our own pain and feeling the pain of others as feeling unjustly treated and empathizing with injustice done to others.

\section{Strength-Based Strategies for Holistic Justice and Connectedness}

Pennell's (this issue) essay can be read as showing that one of the things families do in family group conferences to deal with child protection issues is to formulate a care and protection plan that can tie together various strands of support and meaning in civil society networks. An aunt might agree to meet and talk with a child on a weekly basis to check that she has been getting regular cooked meals. If she finds the child is still going hungry, she might sign off an obligation under the plan to report this to a state social worker (binding a strand of family support to one of state control). The plan might import strands of meaning on commitments to the rights of children that come from state laws that have in turn been shaped by the United Nations children's rights regime. The plan is a little knot that ties together in words that make local sense to the family these national and global strands of meaning. On this view, the family group conference is not guilty of privatizing public issues. Rather, it transmits public issues into private space. Moreover, the knot that ties the aunt into reporting to the state a failure in the conversational regulation of the child's right to nourishment, is a tie that binds the family to make its private problem a public issue in circumstances of self-regulatory failure.

The strengths-based philosophy of the kinds of family group decision making that Pennell has worked with (Burford \& Pennell, 1998) is of particular interest 
from the perspective of nodal governance in civil society (Aral et al., 2002). It is about making nodes of local, mostly extended family, governance strong. Pennell points out that taking strengths seriously can be systematic in a facilitation process that asks families as a first step to list their strengths on pieces of paper. But the strengths-based philosophy can be insinuated rather than institutionalized into the family group decision-making process. The point is to educate participants to try to solve problems by building out from their existing strengths. This is the path to hope and pride in nodal capacity building. Burford and Pennell's (1998) data indeed show that family pride is one of the outcomes better accomplished by these conferences compared to control cases.

Private family time, where state professionals leave the room is also, in the Pennell view, a way of signifying where the strength lies to solve the problems at issue. Her North Carolina data show that private family time was not dominated by professionals but by family members. Private family time is also about empowerment of the family as a decision-making node in civil society. Belgian conferencing practice, which I recently had an opportunity to observe, may be better here in the way it institutionalizes an adjournment in the full conference for "private time" rather than "private family time." This empowers participants to constitute whatever nodes of private plan formulation they want; these nodes might be narrower or wider than the boundaries of the family as they choose, or they might be both narrower (e.g., dyadic) and wider at different moments during the private time adjournment. As Pennell points out, the results are encouraging that this form of nodal governance reduces child maltreatment, holds families together in conditions of enhanced pride in their strengths, and reduces domestic violence. Returning to our wider conception of holism, this encourages the inference that family group decision making simultaneously and reciprocally nurtures justice and connectedness.

\section{Shame and Restorative Justice}

Why does Thomas Scheff (1994) seem to be on to something when he says that it is the open expression of the vulnerable emotions in restorative justice processes - such as shame, fear, and grief - as opposed to aggressive emotionssuch as anger, rage, and self-righteous indignation - that promote sequences of remorse and forgiveness? Strang's (2002) quantitative and qualitative data are consistent with a picture of anger begetting more anger, but of vulnerable emotions like remorse in one participant begetting vulnerable emotions like forgiveness in another. Restorative justice is about flipping vicious circles of hurt begetting hurt into virtuous circles of healing begetting healing. In this, Scheff finds shame to be a particularly important vulnerable emotion, quoting Helen Lynd's (1958) clinical insight: "the very fact that shame is an isolating experience also 
means that if one can find ways of sharing and communicating it, this communication can bring about particular closeness with others." He also makes the point that because the painful emotion of shame is a cross-cultural universal, it is the stuff of powerful intercultural communication when verbal communication fails us.

This is true of forgiveness too: the way soldiers move each other with the offer of a hand or a cigarette, surrounded by their mutual slaughter, as they take their dead behind their trenches. Gestures of forgiveness by enemy soldiers show that forgiveness can heal without being preceded by remorse. I have seen this quite often in conferences - victim forgiveness extended to a lost young person who is a remorseless offender, and then the forgiveness elicits remorse. This is actually a reversal of Scheff's core sequence of remorse eliciting forgiveness, while instantiating his more fundamental insight that laying open one vulnerable emotion can trigger reciprocation with another vulnerable emotion. Ahmed and Braithwaite's (this issue) AMOS analyses cast the most rigorous light to date on the partial validity of both the core remorse to forgiveness (and reconciliation) sequence and the reverse forgiveness and reconciliation to remorse sequence. Scheff's big insight is Humean-when we see others express painful as opposed to aggressive emotions, we see them as human beings like ourselves. Empathy and compassion thus pave the path to healing. Stigmatization blocks that path.

Here there is an interesting connection with Harris's (this issue) data. He reports a strong positive correlation between his measure of shame-guilt by offenders during conferences and empathy on their part. Shame-guilt was also negatively correlated with anger/hostility, while "unresolved shame" was positively correlated with anger/hostility. Harris argues that reintegrative shaming may be important for reducing crime not because it results in shame "but because it provides a mechanism that assists offenders to manage their feeling of shame in more constructive ways." This is consistent with Scheff's conclusion that when someone has been arrested by the police, the situation is already dripping with shame; the question is whether the shame will be covered over or acknowledged and dealt with. Ahmed/Braithwaite and Morrison take this shame management perspective much further in their contributions to the special issue.

We have learnt from experience with restorative justice that shame and pride management skills are not so rare among ordinary members of the community and that the questions observed to routinely succeed in eliciting vulnerable rather than aggressive emotions are quite simple. "How did you feel when you realized your purse was gone?" "How did you feel when the police took you home to tell mum and dad what had happened?" Or when the victim explains how she was hurt by the crime, asking the offender: "What do you think about what happened to me?"

A major debate among restorative justice administrators is whether facilitators should be trained to follow a script to ensure that these are the kinds of questions that are always asked, as opposed to questions that might be more likely to elicit 
aggressive emotions. Another reason some defend script-based training is to prevent facilitators descending into lecturing of wrongdoers, especially if they are police or youth justice officials who must unlearn lifetime habits of telling young offenders what to do. Of course the argument against scripting is that it inhibits flexibility, responsiveness to cultural difference, and the greater authenticity of more spontaneous forms of communication such as humor, which can be such an asset in tense encounters for those who have the gift to use it without offense. We need to be more evidence-based in this debate, as in many others within restorative practice. Randomized controlled trials with assignment to scripted versus unscripted facilitation are needed. In advance of that, we need more systematic naturalistic research that correlates different forms of facilitator questions with responses coded as expressions of aggressive and vulnerable emotion.

Pennell's (this issue) data show that at a more general level, preparation for conferences is important, poor preparation being associated with subsequent manipulation as opposed to empowerment. It may be that Pennell's valoration of greeting (Young, 1995) at the opening of care and protection conferences-for example, by prayer, sharing children's photographs - is another example of a technology of deliberation that conduces to the expression of vulnerable emotions. Again, however, this is an example of an eminently researchable hypothesis that is yet to be tested.

Harris's contribution to this issue shows that criminal offenders randomly assigned to restorative justice conferences perceived others as more disapproving of what they had done, more reintegrative and less stigmatizing than offenders randomly assigned to a criminal trial. Harris finds different kinds of shame-related emotions to be elicited by criminal trials versus conferences. Trials elicit more unresolved shame and more embarrassment exposure, while restorative justice conferences elicit more shame-guilt.

Ahmed, Braithwaite, and Morrison (this issue), on data sets from Bangladesh and Australia respectively, both show that shame displacement (blaming others and directing anger toward them) is a shame management strategy that predicts bullying. In contrast, in both studies shame acknowledgment (accepting that wrong was done and moving on from remorse to repair) is a shame management style associated with lower levels of bullying. Replicating another study by Ahmed (2001), Morrison finds that students who were neither bullies nor victims of bullying managed shame through shame acknowledgment (taking responsibility and making amends) and were less likely to resort to shame displacement (blaming others and externalizing anger). Picking up concepts from Tyler's work, Morrison also found that non-bully non-victims also reported higher levels of pride in membership of the school community and respect within the school.

In an interesting way, these shame and pride management strategies of the non-bully non-victims are contrasted with the rather different shame and pride management pathologies of both bullies and victims of bullying. Bullies displace 
shame into anger without acknowledging shame. Sadly, children who are both bullies and victims end up with the shame management pathologies of both. Bullyvictims both attack others and attack themselves (Nathanson, 1997). Morrison points out that we see this with the horrific cases of children who have been bullied at school and respond by perpetrating massacres at the school and then suicide. An important contribution Morrison makes is bringing to bear an integration of Scheff's theory of unacknowledged shame with reintegrative shaming theory and Tyler's procedural justice theory in accounting for these phenomena.

Morrison has an interesting analysis of victims of bullying as caught up in cycles of persistent shame. On Scheff's (1994) account, they suffer the form of alienation called engulfment. This means an overemphasis on the "we" of who we are, an "I" engulfed by a "we" to which we feel overly beholden. Morrison's interpretation of bullies as characterized by the form of alienation Scheff calls isolation-excessive emphasis of the "I" and rejection of the "we"-seems less persuasive. It may be that bullies are alienated from the wider culture of the school yet engulfed by a delinquent subculture. There is some empirical support for Cohen's (1955) theory of delinquency as a rejection of ones rejectors (Braithwaite, 1989: pp. 21-27). Children who fail in the status system of the school have a status problem that they solve collectively with other children who have been similarly rejected by the status system of the school. They solve it collectively by constituting a delinquent subculture with values that invert those of the school-for example toughness instead of control of aggression, contempt for property instead of respect for property. By inverting the school's values, rejected children collectively create a subculture that interprets them as a success rather than a failure. On this account, violent children follow a trajectory of isolation from the "we" of the school, then engulfment by the "we" of the anti-school gang.

Beyond the effects of shame acknowledgement and shame displacement in reducing and increasing bullying, respectively, both forgiveness and reconciliation (restoring relationships with mutual respect) in parental child-rearing practices predicted lower levels of bullying. Notwithstanding this impact of forgiveness and reconciliation on subsequent bullying, there is a strong case for placing forgiveness and reconciliation as secondary objectives of restorative justice. Forgiveness, and more broadly, reconciling, is a gift. If we promote restorative justice programs as having the objective of eliciting forgiveness, we may give victims of bullying and other wrongs the feeling that they are expected to forgive. Any such expectation undermines the power of forgiveness because it strips it of the generosity and compassionate spontaneity that gives forgiveness its special meaning as a gift from the wronged to the wrongdoer. We can apply the same analysis to apology. Mandating apology denudes its power as a gift from the person who places themselves as wrongdoer by apologizing to the wronged. If we apologize because we are required to, the apology ceases to be a manifestation of a vulnerable emotion. We distrust a coerced apology as insincere, as papering over a deeper truth of 
aggressive emotion. In practice, restorative justice programs that do not set out with the direct objective of eliciting forgiveness and apology roughly double the prospects of both and also quadruple prospects that apologies which are given will be perceived as sincere by victims (Sherman et al., 1998; Strang, 2002, Strang et al., this issue). As with shame and remorse as manifestations of vulnerable emotion, so with forgiveness, reconciliation, and apology: if we directly seek to maximize them, we may destroy their power for good. Restorative justice institutions pursue open expression of vulnerable emotion indirectly by creating spaces with a minimum of domination and a maximum of support from loved ones. This is what encourages people to take risks with articulating their vulnerability.

\section{Conclusion}

It is early days in research and development on restorative justice. Research has lagged behind theory and theory behind practice. Even so, Strang and Sherman's (2005) Campbell Collaboration Review of face to face restorative justice refers to 15 randomized controlled trials, of which only 7 are complete. The Latimer et al. (2001) meta-analysis, which included both experiments and non-experimental studies with satisfactory control groups was able to include 32 studies. Moreover, the explosion of experimental and non-experimental research takes off from a preexisting foundation of multivariate research showing, as Tyler (this issue) points out, that deterrence effects are consistently small in magnitude, that perceived procedural justice effects are stronger, that extrinsic motivations "crowd out" intrinsic motivations to do justice, that punitive parenting is counterproductive. Restorative justice program development has in some important senses aimed at designing justice innovations that apply this research to finding an alternative to regulatory institutions based on Benthamite rational actor presumptions.

Sherman (2003) conceives this challenge (see Morrison, this issue) as developing a new paradigm of "emotionally intelligent justice." The articles in this issue all make important contributions to thinking about justice in terms of nurturing emotional intelligence. They also contribute to seeing conflicts over injustice as opportunities to empower people to learn how to learn in civil society. We live in a world where if justice is to be an accomplishment of our civilization, it will be more an accomplishment of civil society than the state. Certainly, the evidence now seems clear that top-down punitive state justice has limited reach and efficacy. In juxtaposition, all we can say of restorative justice is that it shows promise and, as this special issue illustrates, is engendering a kaleidoscope of institutional innovation. There is a long way to go before we can be evidence-based about which of the colors in the restorative justice rainbow really do enrich justice. There is even further to travel before we discover whether those colors can come together to form a bright white light to lead us from the darkness of the Guantanamo Bays and the school exclusion policies of this world. 


\section{References}

Ahmed, E. (2001). Shame management: Regulating bullying. In E. Ahmed, N. Harris, J. Braithwaite, \& V. Braithwaite (Eds.), Shame management through reintegration (pp. 211-314). Cambridge, UK: Cambridge University Press.

Angel, C. (2005). Crime victims meet their offenders: Testing the impact of restorative justice conferences on victims' post-traumatic stress symptoms. $\mathrm{PhD}$ dissertation, University of Pennsylvania.

Aral, S., Burris, S., \& Shearing, C. (2002). Health and the governance of security: A tale of two systems. The Journal of Law, Medicine \& Ethics, 304, 632-643.

Barnes, G. (1999). Procedural justice in two contexts: Testing the fairness of diversionary conferencing for intoxicated drivers. Unpublished $\mathrm{PhD}$ dissertation, Institute of Criminal Justice and Criminology, University of Maryland.

Bazemore, G., \& Schiff, M. (2005). Juvenile justice reform and restorative justice. Portland, OR: Willan Publishing.

Bonta, J., Jesseman, R., Rugge, T., \& Cormier, R. (2006). Restorative justice and recidivism: Promises made, promises kept? In D. Sullivan \& L. Tifft (Eds.), Handbook of restorative justice: A global perspective. London: Routledge.

Braithwaite, J. (1989). Crime, shame and reintegration. Melbourne: Cambridge University Press.

Braithwaite, J. (2001). Restorative justice and social justice. Saskatchewan Law Review, 63, 185194.

Braithwaite, J. (2002). Restorative justice and responsive regulation. New York: Oxford University Press.

Braithwaite, J. (2005). Markets in vice, markets in virtue. New York: Oxford Univeristy Press.

Burford, G., \& Pennell, J. (1998). Family group decision making project: Outcome report Volume I. St. John's: Memorial University, Newfoundland.

Burnside, J., \& Baker, N. (1994). Relational justice: Repairing the breach. Winchester: Waterside Press.

Cohen, A. K. (1955). Delinquent boys: The culture of the gang. Glencoe, IL: Free Press.

Collins, R. (2004). Interaction ritual chains. Princeton, NJ: Princeton University Press.

Hawkins, K. (2002). Law as last resort: Prosecution decision-making in a regulatory agency. Oxford, UK: Oxford University Press.

Latimer, J., Dowden, C., \& Muise, D. (2001). The effectiveness of restorative justice practices: A meta-analysis. Ottawa: Department of Justice, Canada.

Leventhal, G. S. (1980). What should be done with equity theory? New approaches to the study of fairness in social relationships. In K. Gergen, M. Greenberg, \& R. Willis (Eds.), Social exchanges: Advances in theory and research (pp. 27-55). New York: Plenum.

Lind, E. A., \& Tyler, T. R. (1988). The social psychology of procedural justice. New York: Plenum Press.

Lynd, H. (1958). On shame and the search for identity. New York: Harcourt.

Maxwell, G. M., \& Morris, A. (1993). Family, victims and culture: Youth justice in New Zealand. New Zealand: Social Policy Agency and Institute of Criminology, Victoria University of Wellington.

Nathanson, D. L. (1997). Affect theory and the compass of shame. In M. R. Lansky (Ed.), The widening scope of shame. Hillsdale, NJ: The Analytic Press.

Putnam, R. (2000). Bowling alone: The collapse and revival of American community. New York: Simon Schuster.

Rawls, J. (1971). A theory of justice. Oxford, UK: Oxford University Press.

Roche, D. (2003). Accountability in restorative justice. Oxford, UK: Oxford University Press.

Scheff, T. J. (1994). Bloody revenge: Emotions, nationalism and war. Boulder, CO: Westview Press.

Sherman, L. W. (1993). Defiance, deterrence and irrelevance: A theory of the criminal sanction. Journal of Research in Crime and Delinquency, 30, 445-473.

Sherman, L. W. (2003). Reason for emotion: Reinventing justice with theories, innovations, and research. The American Society of Criminology, 2002 Presidential Address. Criminology, 41, $1-38$.

Sherman, L. W., Strang, H., Barnes, G., Braithwaite, J., Inkpen, N., \& Teh, M. M. (1998). Experiments in restorative policing: A progress report on the Canberra Reintegrative Shaming Experiments 
(RISE). Canberra: Law Program, Research School of Social Sciences, Australian National University.

Singer, T., Seymour, B., O’Doherty, J., Kaube, H., Dolan, R.J., \& Forth, C. D. (2004). Empathy for pain involves the affective but not sensory components of pain. Science, 303, 11571162.

Smith, A. (1790). The theory of the moral sentiments. London: A. Millar.

Strang, H. (2002). Victim participation in a restorative justice process. New York: Oxford University Press.

Strang, H., \& Sherman, L. W. (2005). Effects of face-to-face restorative justice for personal victim crimes. Campbell Collaboration Review. Available at www.campbellcollaboration.org.

Tutu, D. (1999). No future without forgiveness. London: Rider.

Tyler, T. (1990). Why people obey the law. New Haven, CT: Yale University Press.

Tyler, T., \& Blader, S. (2000). Cooperation in groups: Procedural justice, social identity, and behavioral engagement. Philadelphia, PA: Psychology Press.

Tyler, T., \& Dawes, R. M. (1993). Fairness in groups: Comparing the self-interest and social identity perspectives. In B. A. Mellers \& J. Baron (Eds.), Psychological perspectives on justice: Theory and applications. Cambridge, UK: Cambridge University Press.

Tyler, T., \& Huo, Y. J. (2001). Trust and the rule of law: A law-abidingness model of social control. New York: Russel Sage.

Wachtel, T., \& McCold, P. (2001). Restorative justice in everyday life. In H. Strang \& J. Braithwaite (Eds.), Restorative justice and civil society. Melbourne: Cambridge University Press.

Wenzel, M. (2000). Justice and identity: The significance of inclusion for perceptions of entitlement and the justice motive. Personality and Social Psychology Bulletin, 26, 157-176.

Wenzel, M. (2002). The impact of outcome orientation and justice concerns on tax compliance: The role of taxpayers' identity. Journal of Applied Psychology, 87, 629-645.

White, R. (2003). Communities, conferences and restorative social justice. Criminal Justice, 2, 139160.

Young, I. (1995). Communication and the other: Beyond deliberative democracy. In M. Wilson \& A. Yeatman (Eds.), Justice and identity: Antipodean practices. Wellington, New Zealand: Bridget Williams Books.

Zehr, H. (1995). Changing lenses: A new focus for criminal justice. Scottdale, PA: Herald Press.

JOHN BRAITHWAITE is Professor and Australian Research Council Federation Fellow in the Regulatory Institutions Network at the Australian National University. Among his recent publications are Markets in Vice, Markets in Virtue (2005), Restorative Justice and Responsive Regulation (2002), and Shame Management through Reintegration (2001). 